\title{
Pengaruh gaya hidup, kecerdasan emosional dan literasi keuangan terhadap rasionalitas konsumsi mahasiswa pendidikan ekonomi angkatan 2018 Universitas Negeri Malang
}

\author{
Aida Miftachul Jannah, Lisa Rokhmani* \\ Universitas Negeri Malang, Jl. Semarang No. 5 Malang, Jawa Timur, Indonesia \\ *Penulis korespondensi, Surel: lisa.rokhmani.fe@um.ac.id
}

Paper received: 5-7-2021; revised: 23-7-2021; accepted: 30-7-2021

\begin{abstract}
In this modern era, the world is enjoying the phenomenon of increasingly rapid technological development, this phenomenon is called the industrial revolution 4.0. Humans will be required to become more rational individuals in carrying out consumption activities and also to fulfill various desires that arise in them. This study aims to determine the partial and simultaneous influence on lifestyle, emotional intelligence, and financial literacy on consumption rationality in 2018 Economics Education students, State University of Malang. This research uses a quantitative approach with quantitative descriptive research. The population of this research is all students of economic education class 2018 State University of Malang. The technique used in sampling is proportional random sampling. To determine the sample size is calculated using the Slovin formula. This study used a sample of 99 students spread over 6 classes from a population of 131 students. The instruments in this study were questionnaires and multiple-choice tests. The data analysis method in this study uses multiple linear regression analysis with the help of the SPSS version 25 program. The results of the analysis in this study show that: (1) Lifestyle has a significant effect on consumption rationality. (2) Emotional Intelligence has a significant positive effect on consumption rationality. (3) Financial Literacy has a significant positive effect on the rationality of student consumption. (4) Lifestyle, emotional intelligence, and financial literacy affect the consumption rationality of 2018 Economics Education students
\end{abstract}

Keywords: lifestyle; emotional intelligence; financial literacy and consumption rationality

\begin{abstract}
Abstrak
Pada era modern ini dunia sedang menikmati fenomena perkembangan teknologi yang semakin pesat, fenomena ini disebut dengan revolusi industri 4.0. Manusia akan dituntut untuk lebih menjadi individu yang rasional dalam melakukan kegiatan konsumsi dan juga untuk memenuhi berbagai keinginan yang muncul dalam dirinya. Penelitian ini bertujuan untuk mengetahui pengaruh secara parsial dan simultan pada gaya hidup, kecerdasan emosional dan literasi keuangan terhadap rasionalitas konsumsi pada mahasiswa Pendidikan Ekonomi angkatan 2018 Universitas Negeri Malang. Penelitian ini menggunakan pendekatan kuantitatif dengan jenis penelitian deskriptif kuantitatif. Populasi penelitian ini adalah seluruh mahasiswa pendidikan ekonomi angkatan 2018 Universitas Negeri Malang. Teknik yang digunakan dalam pengambilan sampel adalah proportional random sampling. Untuk menentukan besarnya sampel dihitung dengan menggunakan rumus slovin. Penelitian ini menggunakan sampel sebesar 99 mahasiswa yang tersebar di 6 kelas dari populasi yang berjumlah 131 mahasiswa. Instrumen dalam penelitian ini adalah angket dan tes pilihan ganda. Metode analisis data dalam penelitian ini menggunakan analisis regresi linear berganda dengan bantuan program SPSS versi 25. Hasil analisis dalam penelitian menunjukkan bahwa: (1) Gaya Hidup berpengaruh signifikan terhadap rasionalitas konsumsi. (2) Kecerdasan Emosional berpengaruh positif signifikan terhadap rasionalitas konsumsi. (3) Literasi Keuangan berpengaruh positif signifikan terhadap rasionalitas konsumsi mahasiswa. (4) Gaya hidup, kecerdasan emosional dan literasi keuangan berpengaruh terhadap rasionalitas konsumsi mahasiswa Pendidikan Ekonomi angkatan 2018.
\end{abstract}

Kata kunci: gaya hidup; kecerdasan emosional; literasi keuangan dan rasionalitas konsumsi 


\section{Pendahuluan}

Pada era modern ini dunia sedang menikmati fenomena perkembangan teknologi yang semakin pesat, fenomena ini disebut dengan revolusi industri 4.0. Seiring dengan perkembangan teknologi dalam hal transaksi jual beli dan pembayaran menjadi salah satu kebiasaan dan gaya hidup pada masyarakat era modern. Dalam memenuhi kebutuhan, agar sumber daya yang ada dapat digunakan secara efisien, maka dalam melakukan kegiatan konsumsi seseorang juga perlu membuat pilihan dan pertimbangan supaya tercapainya kesejahteraan. Namun dari kemudahan yang ditawarkan, revolusi industri 4.0 juga membawa dampak negatif yang mana akan merubah gaya hidup masyarakat, khususnya pada kebiasaan membelanjakan uang yang dimiliki. Fenomena tersebut menyebabkan sering terjadi kurangnya eksistensi pada masyarakat, khususnya pada kalangan remaja yang akan melakukan berbagai cara untuk mengikuti budaya lingkungannya. Berangkat dari semakin canggihnya teknologi, masyarakat yang lebih mudah mengakses informasi mengenai barangbarang baru melalui media-media sosial, dari media sosial banyak sekali penjual yang menggunakan iklan dengan berbagai modifikasi agar menarik perhatian konsumen, sehingga dari hal tersebut rasionalitas konsumsi masyarakat akan berubah menjadi tidak rasional dan akan meningkatnya tingkat konsumsi bukan hanya untuk memenuhi kebutuhan tetapi juga keinginan untuk memuaskan diri maka muncul perilaku konsumtif.

Balaskrishnan (2000) dalam Sheila, dkk (2016) mengungkapkan bahwa "dalam pemilihan atau pembelian suatu produk seseorang harus lebih mempertimbangkan aspek rasional dari pada aspek efisiensi. Manusia yang rasional akan bertindak sesuai dengan keputusan sehingga dalam pemilihannya pun juga akan lebih selektif, rasionalitas juga cenderung akan berpengaruh pada menurunnya tingkat konsumsi". Mahasiswa Pendidikan Ekonomi angkatan 2018 yang berada pada kalangan menengah ke atas sampai kalangan menengah ke bawah tidak akan terlepas dari perilaku konsumtif.

Gaya hidup merupakan keadaan dimana seseorang mengalami banyak perubahan menjadi lebih modern dalam setiap hal baik tingkah laku maupun sikapnya. Salah satu faktor yang mempengaruhi yaitu budaya barat yang banyak mengeluarkan trend baru. Sesuai dengan pemaparan dari Kanserina (2015: 5) "pemahaman gaya hidup sebagai bagaimana seseorang hidup, bagaimana seseorang itu mengalokasikan waktunya, termasuk juga bagaimana seseorang tersebut mengelola uangnya dan sebagainya". Semakin mewah dan hedonisme gaya hidup seseorang, maka akan semakin meningkatnya perilaku konsumtif dan begitu juga sebaliknya.

Mengawangi (2009) mengungkapkan bahwa "kecerdasan emosional dapat mengatur dan mengontrol emosi yang ada pada diri seseorang yang bertujuan untuk mengontrol perilaku yang dimiliki". Dari hal tersebut bahwa perilaku konsumsi merupakan perilaku manusia yang dapat dikontrol atau dikendalikan dengan kecerdasan emosional yang dimiliki. Literasi keuangan berpengaruh terhadap rasionalitas konsumsi seseorang, yaitu ketika literasi keuangan menurun maka akan terjadi perilaku konsumtif begitu pula sebaliknya, jika literasi keuangan baik maka cenderung terhindar dari perilaku konsumtif Putri \& Lestari, (2019: 1).

Mahasiswa Pendidikan Ekonomi angkatan 2018 merupakan bagian dari para remaja yang selalu mengikuti perkembangan zaman (trend). Kebanyakan dari mereka telah menggunakan uangnya untuk membeli berbagai macam barang yang seharusnya tidak diutamakan, padahal disamping itu mereka juga telah mempelajari bagaimana membuat skala 
prioritas agar dapat membedakan mana kebutuhan dan mana keinginan. Kecerdasan emosionalah yang akan yang akan berperan untuk menciptakan suatu bentuk keputusan yang rasional dalam memenuhi kebutuhan atau mengonsumsi barang dan jasa. Mahasiswa Pendidikan Ekonomi khususnya angkatan 2018 telah memiliki bekal pemahaman yang lebih banyak tentang ekonomi sehingga memiliki kecakapan di bidang ekonomi agar dapat bertindak rasional dalam berkonsumsi.

\section{Metode}

Penelitian ini menggunakan pendekatan kuantitatif dengan jenis penelitian deskriptif kuantitatif yang bertujuan untuk menjabarkan variabel bebas gaya hidup (X1), kecerdasan emosional (X2), dan literasi keuangan (X3) mempengaruhi variabel terikat yaitu rasionalitas konsumsi (Y). Tidak hanya melihat pengaruh dari setiap variabel bebas terhadap variabel terikat parsial, dalam penelitian ini juga akan diteliti bagaimana pengaruh antara gaya hidup, kecerdasan emosional dan literasi keuangan terhadap rasionalitas konsumsi secara keseluruhan. Rancangan penelitian ini secara grafis dapat dilihat pada gambar berikut:

Populasi dalam penelitian ini adalah seluruh mahasiswa S1 Pendidikan Ekonomi angkatan 2018 Universitas Negeri Malang sebanyak 131 mahasiswa dengan sampel 99 mahasiswa yang dihitung dengan menggunakan rumus slovin dan teknik pengambilan sampel yaitu proporsional random sampling.

Pengumpulan data dilakukan dengan menggunakan angket untuk variabel gaya hidup, kecerdasan emosional, literasi keuangan dan rasionalitas konsumsi, sedangkan untuk variabel literasi keuangan menggunakan jenis instrumen tes tertulis. Untuk menguji instrumen maka peneliti melakukan uji coba instrumen dengan menggunakan uji validitas dan uji reliabilitas. Analisis data dalam penelitian ini menggunakan teknik analisis regresi linear berganda.

\section{Hasil dan Pembahasan}

Berdasarkan hasil penelitian, dapat dideskripsikan gambaran masing-masing variabel untuk gaya hidup sebesar 6 mahasiswa Pendidikan Ekonomi angkatan 2018 tidak boros dengan persentase $6 \%$. Terdapat 39 mahasiswa memiliki gaya hidup cukup boros dengan persentase 39,4\%. 39 mahasiswa juga memiliki gaya hidup boros dengan persentase 39,4\%. Dan terdapat 15 mahasiswa memiliki gaya hidup sangat boros dengan persentase 15,2\%.

Kondisi kecerdasan emosional mahasiswa Pendidikan Ekonomi angkatan 2018 dengan klasifikasi sebanyak 6 mahasiswa cukup tinggi dengan persentase $6 \%$. Terdapat 47 mahasiswa memiliki kecerdasan emosional yang tinggi dengan persentase 47,5\%. Dan terdapat 46 mahasiswa juga memiliki kecerdasan emosional sangat tinggi dengan persentase 46,5\%.

Gambaran variabel literasi keuangan mahasiswa Pendidikan Ekonomi angkatan 2018 dengan klasifikasi sebanyak 1 mahasiswa yang kurang dengan persentase 1\%. Terdapat 11 mahasiswa memiliki literasi keuangan cukup baik dengan persentase 11,2\%. Terdapat 29 mahasiswa memiliki literasi keuangan yang baik dengan persentase 29,4\%. Dan terdapat 58 mahasiswa memiliki literasi keuangan sangat baik dengan persentase 58,6\%.

Dan kondisi rasionalitas konsumsi mahasiswa Pendidikan Ekonomi angkatan 2018 terdapat mahasiswa yang memiliki rasionalitas konsumsi dengan klasifikasi sebanyak 3 mahasiswa cukup tinggi dengan persentase 3\%. Terdapat 32 mahasiswa memiliki rasionalitas 
konsumsi yang tinggi dengan persentase 32,3\%. Dan terdapat 64 mahasiswa juga memiliki rasionalitas konsumsi sangat tinggi dengan persentase $64,7 \%$.

Berdasarkan data penelitian, dapat diperoleh regresi berganda dalam penelitian ini adalah sebagai berikut:

Tabel 1. Hasil regresi berganda

\begin{tabular}{llccl}
\hline \multicolumn{1}{c}{ Variabel } & \multicolumn{1}{c}{$\begin{array}{c}\text { Koefisien } \\
\text { Regresi }(\boldsymbol{\beta})\end{array}$} & \multicolumn{1}{c}{ T } & Sig. & Kesimpulan \\
\hline Gaya Hidup & $-0,188$ & $-2,290$ & 0,024 & Signifikan \\
Kecerdasan Emosional & 0,662 & 7,871 & 0,000 & Signifikan \\
& & & & \\
Literasi Keuangan & 0,179 & 2,234 & 0,028 & Signifikan \\
Konstanta = 26.942 & & & & \\
$\mathrm{R}^{2} \quad=0.471$ & & & & \\
$\mathrm{~F}_{\text {hitung } \quad=28.158} \quad$ & & & \\
Sig. F $\quad=0.000$ & & & \\
\hline (Sumber: Hasil Analisis Data) & & &
\end{tabular}

Dari hasil pada tabel tersebut, maka dapat disusun persamaan regresi sebagai berikut:

$$
\mathrm{Y}=\mathrm{a}+\beta_{1} X_{1}+\beta_{2} X_{2}+\beta_{3} X_{3}+\mathrm{e}
$$

$$
\mathrm{Y}=26,942-0,113 \mathrm{X}_{1}+0,708 \mathrm{X}_{2}+0,211 \mathrm{X}_{3}+e
$$

Berdasarkan hasil analisis regresi berganda tersebut, dapat diartikan terjadi pengaruh antara variabel gaya hidup $\left(\mathrm{X}_{1}\right)$, kecerdasan emosional $\left(\mathrm{X}_{2}\right)$ dan literasi keuangan $\left(\mathrm{X}_{3}\right)$ terhadap variabel rasionalitas konsumsi $(\mathrm{Y})$.

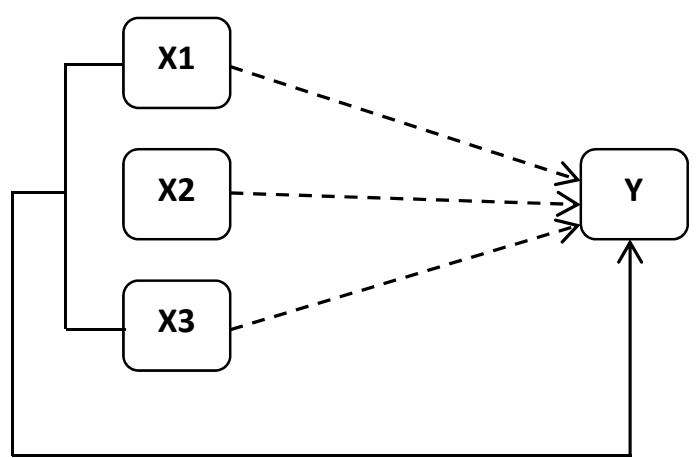

Gambar 1. Hasil analisis regresi

\subsection{Pengaruh Gaya Hidup terhadap Rasionalitas Konsumsi Mahasiswa Pendidikan Ekonomi angkatan 2018 Universitas Negeri Malang}

Berdasarkan penelitian yang telah dilakukan, menunjukkan bahwa secara parsial terdapat pengaruh negatif yang signifikan antara gaya hidup terhadap rasionalitas konsumsi mahasiswa Pendidikan Ekonomi angkatan 2018 Universitas Negeri Malang. Artinya semakin tinggi gaya hidup maka semakin rendah rasionalitas konsumsi mahasiswa, begitupun 
sebaliknya apabila gaya hidup rendah maka semakin tinggi rasionalitas mahasiswa. Sejalan dengan pemikiran Fudyartanta, (2012: 210) bahwa hal ini ditunjukkan dengan sikap mahasiswa yang selalu terbuka dengan hal baru, mereka dengan sangat mudah menerima dan mengikuti perkembangan baru untuk menambah pengalaman. Dengan ditunjang sarana yang memadai, mahasiswa lebih berani mencoba hal baru dan tidak takut mengambil resiko.

Perilaku tersebut dilakukan oleh konsumen untuk menunjang, mendukung, dan meningkatkan konsep diri. Gaya hidup pada Mahasiswa Pendidikan Ekonomi Universitas Negeri Malang Angkatan 2018 dapat berubah, akan tetapi perubahan tersebut bukan disebabkan oleh berubahnya kebutuhan. Pada saat mengalami masa puber, orang tua tidak lagi menjadi model, melainkan orang-orang sebaya yang berada di lingkungan sekitarnya. Sehingga dari kegiatan konsumsi, seseorang dapat dinilai apakah pola hidup yang dijalankan dan konsep diri seperti apa yang dimiliki. Selain itu, semakin mahasiswa tersebut mengikuti perkembangan maka semakin banyak pilihan yang ditawarkan sehingga setelah memenuhi kebutuhan pokok individu akan berkonsumsi sesuai dengan keinginannya dikarenakan banyaknya penawaran yang semakin bervariasi caranya.

\subsection{Pengaruh Kecerdasan Emosional Terhadap Rasionalitas Konsumsi Mahasiswa Pendidikan Ekonomi angkatan 2018 Universitas Negeri Malang}

Berdasarkan penelitian yang telah dilakukan, menunjukkan bahwa secara parsial terdapat pengaruh positif yang signifikan antara kecerdasan emosional terhadap rasionalitas konsumsi mahasiswa Pendidikan Ekonomi angkatan 2018 Universitas Negeri Malang. Dari data yang diperoleh, menunjukkan mahasiswa Pendidikan Ekonomi Universitas Negeri Malang Angkatan 2018 mampu mengendalikan dirinya dan dapat bersosialisasi dengan baik saat melakukan perilaku konsumsi. Sejalan dengan pernyataan Mengawangi (2009) "kecerdasan emosional dapat mengatur dan mengontrol emosi yang ada pada diri seseorang bertujuan untuk mengontrol perilaku yang dimiliki". Jika mahasiswa semakin cerdas maka akan semakin rasional berkonsumsi.

Dari data yang diperoleh mahasiswa Pendidikan Ekonomi angkatan 2018 mampu bersikap baik saat melakukan kegiatan dengan orang lain dan dapat membina hubungan saat melakukan perilaku konsumsi. Selain itu mahasiswa juga mampu mengendalikan emosinya dalam membeli sesuatu yang diinginkan karena mahasiswa cenderung lebih membeli barangbarang yang lebih diperlukan. Hal ini sesuai dengan pernyataan Yantiek (2014: 3) bahwa dalam penelitiannya menempatkan kecerdasan emosional pada pengendalian diri mahasiswa dalam berkonsumsi, dengan kata lain dapat menahan diri agar mampu memenuhi kebutuhan dan keinginannya sehingga bisa mencapai kepuasan dalam berkonsumsi.

\subsection{Pengaruh Literasi Keuangan Terhadap Rasionalitas Konsumsi Mahasiswa Pendidikan Ekonomi angkatan 2018 Universitas Negeri Malang}

Berdasarkan penelitian yang telah dilakukan, menunjukkan bahwa secara parsial terdapat pengaruh yang signifikan antara literasi keuangan terhadap rasionalitas konsumsi mahasiswa Pendidikan Ekonomi angkatan 2018 Universitas Negeri Malang. Sejalan dengan pernyataan Yushita (2017), semakin seseorang tersebut paham dalam keuangan maka akan semakin rasional dalam berkonsumsi. 
Mahasiswa dengan literasi keuangan yang baik akan selektif dalam berkonsumsi akan memprioritaskan kebutuhan dan mengesampingkan keinginan karena mereka tahu kemungkinan-kemungkinan yang terjadi di masa mendatang. Hal ini sesuai dengan pernyataan Program for International Student Assessment (PISA) dalam Litbang Kemendikbud (2012:p. 34) bahwa seseorang yang rasional dalam berkonsumsi akan memiliki perencanaan dan pengelolaan keuangan yang baik dan terstruktur dimana aspek tersebut menjelaskan wawasan keuangan, serta bagaimana pengelolaan dan perencanaan keuangan yang baik dalam jangka panjang maupun jangka pendek, sehingga dapat disimpulkan bahwa penelitian ini mengkaji dan memberi gambaran ada pengaruh positif dan signifikan antara variabel literasi keuangan terhadap rasionalitas konsumsi.

Dengan literasi keuangan yang baik mahasiswa Pendidikan Ekonomi angkatan 2018 mampu melakukan konsumsi yang rasional. Selain itu, pendidikan mengenai konsep keuangan atau literasi keuangan yang efektif akan membantu mahasiswa dalam merencanakan dan mengelola uang saku dalam membuat keputusan kegiatan konsumsi.

\subsection{Pengaruh Gaya Hidup, Kecerdasan Emosional dan Literasi Keuangan Terhadap Rasionalitas Konsumsi Mahasiswa Pendidikan Ekonomi angkatan 2018 Fakultas Ekonomi Universitas Negeri Malang}

Berdasarkan penelitian yang telah dilakukan, menunjukkan bahwa variabel gaya hidup, kecerdasan emosional, dan literasi keuangan mahasiswa secara bersama-sama (simultan) berpengaruh signifikan terhadap rasionalitas konsumsi mahasiswa Pendidikan Ekonomi angkatan 2018 Fakultas Ekonomi Universitas Negeri Malang. Semakin tinggi tingkat gaya hidup, kecerdasan emosional, dan literasi keuangan maka rasionalitas konsumsi tersebut semakin tinggi. Dari keseluruhan variabel yaitu gaya hidup, kecerdasan emosional dan literasi keuangan yang mempengaruhi rasionalitas konsumsi, pengaruh terbesar ada pada variabel kecerdasan emosional. Hal ini dapat disimpulkan bahwa semakin mahasiswa yang memiliki gaya hidup dan literasi keuangan yang baik dan ditunjang kecerdasan emosional yang baik maka akan menjadi individu yang semakin rasional dalam berkonsumsi.

Hasil penelitian menunjukkan bahwa sumbangan efektif ketiga variabel bebas (gaya hidup, kecerdasan emosional dan literasi keuangan) terhadap variabel terikat (rasionalitas konsumsi) hampir 50\% (berdasarkan hasil $\mathrm{R}^{2}$ ). Dari keseluruhan variabel yaitu gaya hidup, kecerdasan emosional dan literasi keuangan yang mempengaruhi rasionalitas konsumsi, menunjukkan bahwa semakin tinggi variabel bebas, maka semakin tinggi rasionalitas konsumsi yang disebabkan adanya perubahan-perubahan sosial baik dalam individu maupun lingkungan masyarakat. Seorang mahasiswa akan mampu menyikapi berbagai perubahan sosial yang terjadi di sekitarnya dengan baik tanpa menghilangkan jati dirinya sehingga rasionalitas dalam berkonsumsi dapat terwujud.

\section{Simpulan}

Berdasarkan hasil penelitian dan pembahasan, maka dapat disimpulkan bahwa: (1) Terdapat pengaruh gaya hidup terhadap rasionalitas konsumsi Mahasiswa Pendidikan Ekonomi Angkatan 2018 Fakultas Ekonomi Universitas Negeri Malang; (2) Terdapat pengaruh kecerdasan emosional terhadap rasionalitas konsumsi Mahasiswa Pendidikan Ekonomi Angkatan 2018 Fakultas Ekonomi Universitas Negeri Malang; (3) Terdapat pengaruh literasi keuangan terhadap rasionalitas konsumsi Mahasiswa Pendidikan Ekonomi Angkatan 2018 
Fakultas Ekonomi Universitas Negeri Malang; (4) Terdapat pengaruh gaya hidup, kecerdasan emosional dan, literasi keuangan terhadap rasionalitas konsumsi Mahasiswa Pendidikan Ekonomi Angkatan 2018 Fakultas Ekonomi Universitas Negeri Malang.

Saran yang dapat diajukan dari hasil penelitian ini antara lain sebagai berikut: (1) Gaya hidup mahasiswa Pendidikan Ekonomi angkatan 2018 hendaknya harus lebih mengarahkan gaya hidup mereka ke arah yang lebih positif seperti tanggung jawab, kemandirian, kejujuran dan optimalisasi dalam melakukan konsumsi yang rasional; (2) Kecerdasan emosional mahasiswa Pendidikan Ekonomi angkatan 2018 seharusnya lebih ditingkatkan agar memiliki rasionalitas konsumsi yang lebih baik lagi di dalam dirinya; (3) Dapat meningkatkan literasi keuangan dan diterapkan ke dalam aspek-aspek kehidupan sehari-hari agar lebih rasional terutama dalam berperilaku konsumsi; (4) Untuk meningkatkan rasionalitas konsumsi pada mahasiswa Pendidikan Ekonomi angkatan 2018, sebaiknya mahasiswa harus dapat menyeimbangkan antara gaya hidup dengan kecerdasan emosional dan literasi keuangan, mengingat kecerdasan emosional dan literasi keuangan memiliki pengaruh secara bersama terhadap rasionalitas konsumsi; (5) Bagi Peneliti Selanjutnya penelitian ini dapat digunakan untuk pertimbangan melakukan penelitian selanjutnya, karena masih terdapat banyak aspek yang dapat mempengaruhi rasionalitas konsumsi. Maka disarankan bagi peneliti selanjutnya untuk sebaiknya menambahkan variabel lain yang dapat mempengaruhi rasionalitas konsumsi di luar variabel yang diteliti seperti modernitas, perilaku konsumsi, lingkungan keluarga, kelompok teman sebaya, dan lain sebagainya. Penggunaan wilayah populasi yang lebih luas agar ruang lingkup hasil penelitian lebih menyeluruh.

\section{Daftar Rujukan}

Amalia, Euis \& Rianto, Nur. (2010). Teori Mikro Ekonomi. Jakarta: Kencana Prenata Media Grup

Fuad, A. (2015). Pengaruh Gaya Hidup Terhadap Keputusan Pembelian Konsumen Di Purworejo. Segmen

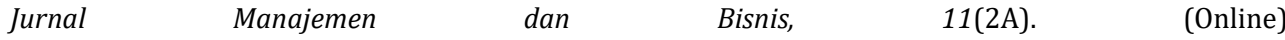
(http://ejournal.umpwr.ac.id/index.php/segmen/article/view/3791/3572) diskses 14 Desember 2020

Fudyartana, Ki. (2012). Psikologi Perkembangan. Pustaka Pelajar: Yogjakarta

Ghozali, I. (2016). Aplikasi Analisis Multivariat dengan Program IBM SPSS 23, Edisi 7. Universitas Diponegoro. Semarang.

Goleman. (2007). Emotional Intellegance. Terj. Hermaya. Jakarta: PT Gramedia Pustaka Utama.

Gyovani, E., \& Haryono, A. (2018). Dampak Kecerdasan Emosi Remaja Dan Respon Iklan Di Media Sosial Terhadap Penerapan Prinsip Ekonomi Kegiatan Konsumsi Siswa Kelas Xi Ips di Sma Negeri 1 Kepanjen. Jurnal Pendidikan Ekonomi, 11(1), 29-40. (http://journal2.um.ac.id/index.php/jpe/article/view/2956) diskses 25 November 2020

Houston, B. E. (2011). Dasar-Dasar Manajemen Keuangan. Edisi 11. Jakarta: Salemba Empat.

Kanserina, D., Haris, I. A., \& Nuridja, I. M. (2015). Pengaruh Literasi Ekonomi dan Gaya Hidup Terhadap Perilaku Konsumtif Mahasiswa Jurusan Pendidikan Ekonomi Universitas Pendidikan Ganesha Tahun. Jurnal $\begin{array}{llll}\text { Pendidikan Ekonomi Undiksha, } & \text { 5(1). }\end{array}$ (https://ejournal.undiksha.ac.id/index.php/JJPE/article/view/5213) diakses 2 Desember 2020

Lusardi, A., \& Mitchell, O. S. (2011). Financial literacy and planning: Implications for retirement wellbeing (No. w17078). National Bureau of Economic Research.

Mahrunnisya, D. (2018). Pengaruh Kecerdasan Emosional dan Konformitas Teman Sebaya melalui Money Attitude terhadap Perilaku Konsumtif pada Siswa IPS SMA Negeri Kota Bandar Lampung (Doctoral dissertation, UNS (Sebelas Maret University)).

Mengawangi, R. (2009). Pendidikan karakter solusi tepat untuk membangun bangsa.

Monks, J. F., \& Knoers, A. M. P. (2014). Psikologi Perkembangan; Pengantar dalam berbagai bagiannya. 
Novitasani, L. (2014). Perubahan Gaya Hidup Konsumtif Pada Mahasiswa Urban di UNESA. Paradigma, 2(3). (Online)(https://jurnalmahasiswa.unesa.ac.id/index.php/paradigma/article/view/9090/8922)

Oktafikasari, E., \& Mahmud, A. (2017). Konformitas Hedonis dan Literasi Ekonomi Tehadap Perilaku Konsumtif Melalui Gaya Hidup Konsumtif (Studi Kasus pada Mahasiswa Bidikmis 2014 di Universitas Negeri Semarang). Economic Education Analysis Journal, 4(2), 496-50. (Online) (https://journal.unnes.ac.id/sju/index.php/eeaj/article/view/20280

P. Robbins Stephen. (2002). Perilaku Ekonomi Edisi Kelima. Jakarta. Erlangga

Patricia, N. L., \& Handayani, S. (2014). Pengaruh gaya hidup hedonis terhadap perilaku konsumtif pada pramugari maskapai penerbangan "X". Jurnal Psikologi Esa Unggul, 12(01), 127078. (Online) (https://www.esaunggul.ac.id/wp-content/uploads/2019/11/127078-ID-pengaruh-gaya-hiduphedonis-terhadap-per.pdf)

Putranto Urip. (2006). Buku Ajar Ekonomi untuk SMP kelas VII. Surakarta: Citra Pustaka

Putri, S. F., Widodo, J., \& Martono, S. (2016). Pengaruh Literasi Keuangan Melalui Rasionalitas Terhadap Perilaku Konsumtif (Studi Kasus Siswa Kelas XI Ilmu Sosial SMA Negeri se-Kota Semarang). Journal of Economic Education, 5(2), 179-192. (https://journal.unnes.ac.id/sju/index.php/jeec/article/view/13047)

Sabran. (2014). Manajemen Pemasaran. Jakarta: Erlangga.

Setiadi, N. J., \& SE, M. (2019). Perilaku Konsumen: Perspektif Kontemporer pada Motif, Tujuan, dan Keinginan Konsumen Edisi Ketiga (Vol. 3). Prenada Media.

Subandi, D. MM (2011). Ekonomi Koperasi (Teori dan Praktek).

Sugiyono. (2011). Metode Penelitian Kuantitatif, Kualitatif, dan R \& B. Bandung: PT Alfabeta.

Suyanto. (2014). Sosiologi Ekonomi: Kapitalisme dan Konsumsi di Era Masyarakat Post-Modernisme. Jakarta: Kencana Prenada Media Group

Syakhabyatin, I., \& Jubaedah, J. (2017). Rasionalitas Konsumen Dalam Perspektif Islam. Tsarwah, 1(01), 53-68. (Online), (http://www.jurnal.uinbanten.ac.id/index.php/tsarwah/article/view/129) diskses 10 Desember 2020

Torell, L. Allen Neil R. Rimbey, Octavio A. Ramirez dan Daniel W. McCollum. (2005). "Income Earning Potential versus Consumptive Amenities in Determining Ranchland Values". Journal of Argicultural and Resource Economics Vol. 30 (3): 537-560.

Wahidah, N. (2013). Pengaruh Perilaku Konsumtif Terhadap Gaya Hidup Mahasiswa Pendidikan Ekonomi Fkip UNTAN. Jurnal Pendidikan dan Pembelajaran Khatulistiwa, 3(2). (Online), (https://jurnal.untan.ac.id/index.php/jpdpb/article/view/4610) diskses 2 Desember 2020

Yantiek, E. (2014). Kecerdasan emosi, kecerdasan spiritual dan perilaku prososial remaja. Persona: Jurnal Psikologi Indonesia, 3(01). (Online), (jurnal.untag-sby.ac.id/index.php/persona/article/view/366) diskses 16 Desember 2020

Yushita, A. N. 2017. Pentingnya literasi keuangan bagi pengelolaan keuangan pribadi. Nominal: Barometer Riset $\begin{array}{lllll}\text { Akuntansi dan } & \text { Manajemen, } & \text { 11-26. }\end{array}$ (https://journal.uny.ac.id/index.php/nominal/article/view/14330) diakses 9 November 2020 